Nature 372, 281; 1994), but he was able to see a proof copy. Their accounts "basically match up".

Rhodes's chapter on the design, construction and testing of the US Ivy Mike, the first ever thermonuclear device, in November 1952 is full of fascinating detail. A huge scientific experiment rather than a weapon test- although the device was later weaponized - it was a cryogenic design using liquid deuterium and a small quantity of tritium. It yielded 10.4 megatons, vaporized the coral isle of Elugelab and produced a cloud 100 miles wide. Its fireball created "every element ever assembled in the universe", plus new transuranic species such as element 100 (later called fermium).

The next US hydrogen bomb trials the Castle series in the spring of 1954 - tested six different designs of staged bombs using solid fuel in the form of lithium deuteride. The first shot, the notorious Bravo, with a greater than expected yield of 15 megatons, contaminated a Japanese fishing vessel, the Lucky
Dragon, caused severe fallout on the Marshall Islands and aroused worldwide protest.

To encompass so much in one book is a formidable undertaking, brilliantly carried out and fully justified by the symbiotic Cold War relationship of the two superpowers. Their weapons programmes influenced each other profoundly. It was the first Soviet atom bomb test in August 1949 that panicked the United States into an all-out concentrated effort to develop hydrogen bombs; the extreme vulnerability of the Soviet Union to nuclear attack gave overwhelming urgency to the efforts of the Soviets, for they must have known that some Americans wanted a preventive war and that General LeMay envisaged the destruction of 70 Soviet cities in 30 days, with 6.7 million deaths and casualties among the civilian population.

Espionage was a very important element in this relationship. The Soviet Union obtained many thousands of classified documents, some of which Igor Kurchatov himself considered to be "of immense value to our science and our country". The espionage factor also greatly influenced US politics.

The final chapter of Dark Sun asks some interesting questions: for example, what is a hydrogen bomb and what part have semantics played in US weapon development? (A great deal, apparently, unlike the more rationally conceived Soviet programme). The chapter also asks some profound questions about the past and the future and the 'new singularity'. This most rewarding book is unique in the grim grandeur of its scope, the richness and originality of its content, and its deep and humane understanding.

Lorna Arnold is at UKAEA Government Division, 329 Harwell, Oxfordshire OX11 ORA, UK.

Dark Sun is also available on four audio cassettes, read by the author (Simon and Schuster Audio, \$25); and Richard Rhodes's award-winning The Making of the Atomic Bomb has just been reissued in paperback by Touchstone Books at $\$ 16$.

\title{
Remembering the dawn of the nuclear age
}

SEVERAL other new books have been published to mark the fiftieth anniversary of the atomic bombings of Hiroshima and Nagasaki, the end of the Second World War and the start of the nuclear age.

Concentrating on why the bomb was dropped are Hiroshima: Why America Dropped the Bomb (Little, Brown, \$19.95) by Ronald Takaki, who examines Harry Truman's "troubled ambivalence" over the attack, and The Decision to Use the Bomb (Knopf, \$32.50) by Gar Alperovitz, who argues that the United States dropped the bomb to impress the Soviets rather than avoid costly invasion.

Such historical controversies about the use of the bomb are neatly summed up by Robert Jay Lifton and Greg Mitchell in Hiroshima in America: Fifty Years of Denial (Grosset/Putnam, \$27.50). But their main aim is to show that Americans are still unwilling to face the truth about Hiroshima. "By confronting the legacy of Hiroshima," they write, "and exploring what it has done to living and dying in the late twentieth century, we embark on a path of psychological and political renewal".

More straightforward factual views appear in Adrian Weale's informative Eye-Witness Hiroshima (Robinson/Carroll and Graf, £5.99/\$10.95), a paper-

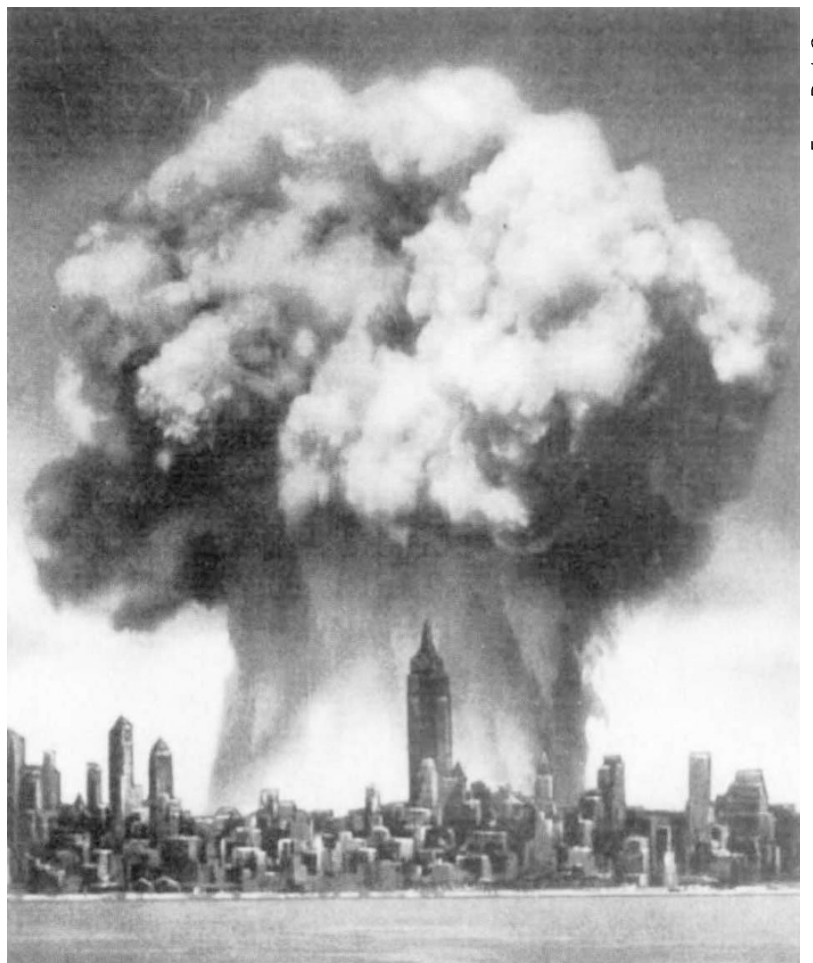

The Bikini Baker atomic bomb (see page 475).

back collection of first-hand accounts of the development and use of the atomic bomb, from the perspective of the military, scientists, politicians and survivors.

A meticulously detailed record of the war's last month is given by Stanley Weintraub in The Last Great Victory (Dutton, \$35), which interweaves the momentous events with fascinating personal stories.

And the development of the atom bomb is traced through 280 pictures (many never before published) in Picturing the Bomb: Photographs from the Secret World of the Manhattan Project (Abrams, $£ 39.95$, September) by Rachel Fermi (granddaughter of Enrico Fermi) and Esther Samra.

Survivors and witnesses revisit the Japanese bombing in Nagasaki Journey: The Photographs of Yosuke Yamahata, August 10, 1945 (Pomegranate Artbooks, \$22.95); Children of the Atomic Bomb: An American Physician's Memoir of Nagasaki, Hiroshima and the Marshall Islands (Duke University Press, \$16.95) by James N. Yamazaki (with Louis B. Fleming); Hiroshima Notes (Marion Boyars, \$22.95) a collection of essays from the 1960 s by the Japanese pacifist and novelist Kenzaburo Oe, winner of last year's Nobel prize for literature; White Flash, Black Rain: Women of Japan Relive the Bomb (Milkweed Editions, \$12.95), an anthology of prose and poetry; and Writing Ground Zero: Japanese Literature and the Atomic Bomb by John Whittier Treat (University of Chicago Press, \$34.95).

Peter Tallack 